\title{
Genetic and biological characteristics of avian influenza virus subtype H1N8 in environments related to live poultry markets in China
}

Ye Zhang ${ }^{1+}$, Jie Dong ${ }^{1+}$, Hong Bo ${ }^{1}$, Libo Dong ${ }^{1}$, Shumei Zou' ${ }^{1}$, Xiyan Li ${ }^{1}$, Yuelong Shu ${ }^{1,2}$ and Dayan Wang ${ }^{1 *}$ (D)

\begin{abstract}
Background: Since 2008, avian influenza surveillance in poultry-related environments has been conducted annually in China. Samples have been collected from environments including live poultry markets, wild bird habitats, slaughterhouses, and poultry farms. Multiple subtypes of avian influenza virus have been identified based on environmental surveillance, and an H1N8 virus was isolated from the drinking water of a live poultry market.

Methods: Virus isolation was performed by inoculating influenza A-positive specimens into embryonated chicken eggs. Next-generation sequencing was used for whole-genome sequencing. A solid-phase binding assay was performed to test the virus receptor binding specificity. Trypsin dependence plaque formation assays and intravenous pathogenicity index tests were used to evaluate virus pathogenicity in vitro and in vivo, respectively. Different cell lines were chosen for comparison of virus replication capacity.

Results: According to the phylogenetic trees, the whole gene segments of the virus named A/Environment/Fujian/ 85144/2014(H1N8) were of Eurasian lineage. The HA, NA, PB1, and M genes showed the highest homology with those of H1N8 or H1N2 subtype viruses isolated from local domestic ducks, while the PB2, PA, NP and NS genes showed high similarity with the genes of H7N9 viruses detected in 2017 and 2018 in the same province. This virus presented an avian receptor binding preference. The plaque formation assay showed that it was a trypsindependent virus. The intravenous pathogenicity index (IVPI) in chickens was 0.02. The growth kinetics of the A/Environment/Fujian/85144/2014(H1N8) virus in different cell lines were similar to those of a human-origin virus, A/Brisbane/59/2007(H1N1), but lower than those of the control avian-origin and swine-origin viruses.

Conclusions: The H1N8 virus was identified in avian influenza-related environments in China for the first time and may have served as a gene carrier involved in the evolution of the H7N9 virus in poultry. This work further emphasizes the importance of avian influenza virus surveillance, especially in live poultry markets (LPMs). Active surveillance of avian influenza in LPMs is a major pillar supporting avian influenza control and response.
\end{abstract}

Keywords: Avian influenza virus, H1N8 subtype, Live poultry market

\footnotetext{
* Correspondence: dayanwang@cnic.org.cn

${ }^{\dagger} Y$ Zhang and J Dong contributed equally to this article

${ }^{1}$ Chinese National Influenza Centre, National Institute for Viral Disease Control

and Prevention, Chinese Center for Disease Control and Prevention; WHO

Collaborating Center for Reference and Research on Influenza; Key

Laboratory for Medical Virology, National Health and Family Planning

Commission, Beijing, China

Full list of author information is available at the end of the article
}

(c) The Author(s). 2019 Open Access This article is distributed under the terms of the Creative Commons Attribution 4.0 International License (http://creativecommons.org/licenses/by/4.0/), which permits unrestricted use, distribution, and reproduction in any medium, provided you give appropriate credit to the original author(s) and the source, provide a link to the Creative Commons license, and indicate if changes were made. The Creative Commons Public Domain Dedication waiver (http://creativecommons.org/publicdomain/zero/1.0/) applies to the data made available in this article, unless otherwise stated. 


\section{Background}

Both animal and human infections with influenza A virus have been reported. Sometimes mammals, such as pigs, horses, and seals, and poultry can be infected under natural conditions. Wild aquatic birds are the major reservoir of avian influenza, harbouring 16 haemagglutinin (HA) and 9 neuraminidase (NA) subtypes of viruses [1]. Although avian influenza viruses present limited replication ability in humans, direct human infection with avian influenza and pandemics caused by reassortment of human influenza have both occurred. To date, human infections have been reported with the H5, H6, H7, H9, and $\mathrm{H} 10$ influenza virus subtypes [2, 3].

Exposure to live poultry markets (LPMs) is an important risk factor for highly pathogenic avian influenza infection. Closure of LPMs has been reported to be efficient in blocking avian influenza transmission [4, 5]. In China, LPMs are major places enabling influenza dissemination and potential reassortment because of the high densities and the mixture of poultry, pet birds, and wild birds that are often present in LPMs. LPMs are also considered valuable places for influenza ecology research and research on the emergence and re-emergence of influenza type A virus [6]. Therefore, avian influenza surveillance in LPMs provides not only clues for tracing infection sources but also evidence for risk assessment and decision making [7-9].

Along with avian influenza control and prevention, regular LPM surveillance has been conducted in China annually since 2008. Specimens are sampled from relevant environments, and viruses are isolated and identified. The distribution and prevalence of influenza $\mathrm{A}$ virus subtypes in LPMs are then analysed. Multiple subtypes of avian influenza virus have been identified in the more than 10 years of surveillance. One avian influenza virus subtype, H1N8, which is uncommon among animals and animal-associated environments, was identified from poultry drinking water in a LPM in Fujian Province in 2014. To better understand its potential risk to human health, studies were conducted on the genetic and biological characteristics of the virus.

\section{Methods}

RNA extraction and real-time RT-PCR

A QIAamp Viral RNA Mini Kit (Qiagen, Hilden, Germany) was used to carry out RNA extraction. Real-time reverse transcription polymerase chain reaction (RT-PCR) assays for the influenza A were performed on each of the samples. The reactions were carried out using an AgPath-ID ${ }^{\mathrm{m}}$ One-Step RT-PCR Kit (ThermoFisher, Waltham, USA) under the following conditions: $10 \mathrm{~min}$ at $45^{\circ} \mathrm{C} ; 10 \mathrm{~min}$ at $95^{\circ} \mathrm{C}$; and 40 cycles of $15 \mathrm{~s}$ at $95^{\circ} \mathrm{C}$ and $45 \mathrm{~s}$ at $60^{\circ} \mathrm{C}$. The sequences of the primers and probe are as follows: forward primer,
5'GACCRATCCTGTCACCTCTGAC3'; reverse primer, 5'A GGGCATTYTGGACAAAKCGTCTA3'; and probe, 5'FA M-TGCAGTCCTCGCTCACTGGGCACG-BHQ1-3'.

\section{Virus amplification}

Viruses or influenza A-positive specimens were inoculated into the allantoic cavity of 9-day-old embryonated chicken eggs for $48 \mathrm{~h}$ at $37^{\circ} \mathrm{C}$ for virus propagation. The allantoic fluid was harvested, and haemagglutination assays were performed using $1 \%$ turkey red blood cells to detect the titres of the influenza viruses.

\section{Full-genome sequencing}

PathAmp FluA Reagents (ThermoFisher, Waltham, USA) were used to amplify the full genome. The primer sequences were as follows: 5' -CTGGATACGCCAGCRAA AGCAGG-3' (sense) and 5'-GACCTGATGCGGAGTAGAAACAAGG-3' (antisense). Whole-genome sequencing was then performed on an Ion Torrent ${ }^{\text {TM }}$ Personal Genome Machine $^{\mathrm{Ts}}$ platform (Thermo Fisher Scientific) with a read length of 200 base pairs following the instructions, and the data were analysed using CLC Genomics Workbench 7.5.1 software.

\section{Phylogenetic analysis}

Phylogenetic analysis was performed using MEGA7.0, and a phylogenetic tree was constructed using the maximum likelihood method. The bootstrap value was tested with 1000 replications for each gene segment. Homology analysis of nucleic acids was performed on the NCBI website with the BLAST platform.

\section{Receptor binding analysis}

A solid-phase binding assay was used as described previously $[10,11]$. Synthetic sialylglycopolymers, including 3'-SLN, 6'-SLN, 3'-SL, and 6'-SL (referring to Neu5Aco2, 3Gal/1-4GlcNAc, Neu5Ac $\alpha 2,6$ Gal $\beta 1-4 G l c N A c, N e u 5 A-$ c $\alpha 2,3 \mathrm{Gal} \beta 1-4 \mathrm{Glc}$, and Neu5Ac $\alpha 2,6 \mathrm{Gal} \beta 1-4 \mathrm{Glc}$, respectively), were coated on the plates. For testing, 32 haemagglutination units (HAUs) of each virus were added to each well. ELISA was then performed. The primary antibody was a universal monoclonal antibody against group I HAs, and a goat anti-human IgG-HRP antibody was chosen as the secondary antibody. A tetramethylbenzidine (TMB) substrate solution (BD Biosciences) was used to develop the results. The optical density was read at $450 \mathrm{~nm}$.

\section{Trypsin dependence plaque formation assay}

Virus pathogenicity in vitro can be reflected by plaque formation with or without trypsin. The plaque formation protocol was performed as follows: 96-well MDCK plates with $3 \times 10^{4}$ cells/well were cultured at $37^{\circ} \mathrm{C}$ overnight. Serial dilutions of virus were inoculated into 
MDCK cells. Two hours after virus absorption, overlay medium (2× DMEM and Avicel) with or without trypsin (final concentration of $2 \mu \mathrm{g} / \mathrm{ml}$ ) was prepared and added. The cell plates were fixed with $4 \%$ paraformaldehyde 1 day later. ELISA was performed with a mouse monoclonal antibody against influenza type A (CDC-WHO kit used at 1:2000 in ELISA buffer) as the primary antibody and a goat anti-mouse IgG $(\mathrm{H}+\mathrm{L})$ HRP conjugate (Bio-Rad 172-1011, used at 1:1000 in ELISA Buffer) as the secondary antibody. Finally, plaque formation was visualized by adding True Blue ${ }^{\text {Tx }}$ peroxidase substrate (KPL 50-78-02) and $0.03 \% \mathrm{H}_{2} \mathrm{O}_{2}$ (1:1000 dilution of a $30 \%$ solution) [12].

\section{Intravenous pathogenicity index test in chicken}

Five-week-old specific pathogen-free (SPF) leghorn chickens were purchased from the company Beijing Vital River Laboratory Animal Technology. According to the OIE/WHO guidelines [13], the chickens were divided into two groups. One group with 10 chickens was infected intravenously with $100 \mu \mathrm{l}$ of diluted test virus (fresh allantoic fluid diluted 1:10 with sterile isotonic saline). The other group, with 2 chickens, was infected intravenously with $100 \mu$ of isotonic saline. The chickens were observed for 10 days.

\section{Virus replication kinetics in DF1, A549 and PK15 cells}

The virus replication capacity in mammalian cells was evaluated. Human type II alveolar epithelial cell line (A549), chicken embryo fibroblasts cell line DF1 (DF1), and porcine kidney cell line (PK15) were inoculated into 96-well plates at a density of $3 \times 10^{4}$ cells/well at $37^{\circ} \mathrm{C}$ overnight, and the test viruses were added with a multiplicity of infection of 0.01 . The plates were then incubated with DMEM containing 0.5\% BSA and $2 \mu \mathrm{g} / \mathrm{ml}$ TPCK-treated trypsin at $37^{\circ} \mathrm{C}$. The supernatants were collected at 12, 24, 36, 48, 60 and $72 \mathrm{~h}$ post infection. End-point titration of the supernatants was performed with MDCK cells.

\section{Statistical analysis}

The statistical significance of the differences was determined using $\mathrm{T}$ tests, and $P<0.05$ was considered to indicate a significant difference.

\section{Results}

\section{Homology analysis}

The avian influenza virus subtype H1N8 identified in this study was named A/Environment/Fujian/85144/ 2014(H1N8); the full genome sequences of the virus have been uploaded to the Global Initiative on Sharing All Influenza Database (GISAID) with accession numbers EPI11315724-EPI11315731. The nucleotide homology analysis of A/Environment/Fujian/85144/2014 showed that it might be a reassortant virus. Three of the 8 segments, HA, $\mathrm{NA}$ and PB2, were derived from an A/Duck/Fujian/13/ 2013 (H1N8)-like virus; the PB2, PA, and NS genes showed the highest similarity with the H7N9 virus A/Environment/Fujian/S10058/2017(H7N9). NP and M were most closely related to the H1N2 viruses A/Environment/ Fujian/FJ1273/2014 and A/duck/Guangxi/GXd-2/2012, respectively (Table 1 ).

\section{Molecular characteristics}

The HA cleavage site of the H1N8 subtype virus had a PSVQSR/GLF motif, which presented low pathogenic avian influenza properties. The Q226L or G228S mutation in HA, which is related to human-type receptor binding preference, was not detected in the H1N8 virus in this study. The E627K and D701N substitutions (molecular markers related to increased virulence in mammals [14]) of the PB2 protein were not detected. The N30D and T215A substitutions of the M1 protein were found in the H1N8 virus, and this mutation has been reported to be associated with increased pathogenicity of the H5N1 virus in mice [15]. No neuraminidase inhibitor or amantadine resistance mutations [16] were found in the NA protein of the H1N8 virus. The NS1 amino acid at position 42 was $A$ instead of S, which indicated that the P42S substitution related to increased virulence in mice [17] was not present in the H1N8 virus (Table 2).

Table 1 Nucleotide homology of the A/Environment/Fujian/85144/2014 (H1N8) virus with the most closely related strains in GenBank Database

\begin{tabular}{llll}
\hline Gene segment & Virus with the highest nucleic acid homology & Percent Homology (\%) & GenBank ID \\
\hline PB2 & A/environment/Fujian/S10058/2017(H7N9) & 99 & MH209528.1 \\
PB1 & A/duck/Fujian/13/2013(H1N8) & 99 & KP658098.1 \\
PA & A/environment/Fujian/S10058/2017(H7N9) & 99 & MH209530.1 \\
HA & A/duck/Fujian/13/2013(H1N8) & 99 & KP658038.1 \\
NP & A/environment/Fujian/FJ1273/2014(H1N2) & 99 & KP658061.1 \\
NA & A/duck/Fujian/13/2013(H1N8) & 99 & KP658023.1 \\
M & A/duck/Guangxi/GXd-2/2012(H1N2) & 99 & KF013935.1 \\
NS & A/environment/Fujian/S10058/2017(H7N9) & 99 & MH209535.1 \\
\hline
\end{tabular}


Table 2 Key molecular markers of the A/Environment/Fujian/ 85144/2014 (H1N8) virus

\begin{tabular}{|c|c|c|}
\hline Function & $\begin{array}{l}\text { Amino- Acid } \\
\text { Mutation }\end{array}$ & $\begin{array}{l}\text { Molecular characteristics } \\
\text { of A/Environment/Fujian/ } \\
85144 / 2014(\mathrm{H} 1 \mathrm{~N} 8)\end{array}$ \\
\hline \multicolumn{3}{|l|}{ HA } \\
\hline HA cleavage & & PSVQSR/GLF \\
\hline \multirow{2}{*}{$\begin{array}{l}\text { Human receptor } \\
\text { binding(H3 } \\
\text { numbering) }[14]\end{array}$} & Q226L & Q \\
\hline & G228S & G \\
\hline \multicolumn{3}{|l|}{ NA } \\
\hline \multirow{4}{*}{$\begin{array}{l}\text { Resistant to oseltamivir } \\
\text { or zanamivir (N2 } \\
\text { numbering) [15] }\end{array}$} & R292K & $\mathrm{R}$ \\
\hline & $\mathrm{H} 274 \mathrm{Y}$ & $\mathrm{H}$ \\
\hline & E119V & $E$ \\
\hline & R152K & $\mathrm{R}$ \\
\hline \multicolumn{3}{|l|}{ PB2 } \\
\hline $\begin{array}{l}\text { Increased virulence in } \\
\text { mice [16] }\end{array}$ & E627K & $E$ \\
\hline $\begin{array}{l}\text { Enhances pathogenicity } \\
\text { in mice [16] }\end{array}$ & D701N & $\mathrm{D}$ \\
\hline \multicolumn{3}{|l|}{ M1 } \\
\hline \multirow{2}{*}{$\begin{array}{l}\text { Increased virulence } \\
\text { in mice [17] }\end{array}$} & N30D & $\mathrm{D}$ \\
\hline & $\mathrm{T} 215 \mathrm{~A}$ & A \\
\hline \multicolumn{3}{|l|}{ M2 } \\
\hline Resist to amantadine & S31 N & S \\
\hline \multicolumn{3}{|l|}{ NS1 } \\
\hline $\begin{array}{l}\text { Increased virulence } \\
\text { in mice [18] }\end{array}$ & P42S & A \\
\hline
\end{tabular}

\section{Phylogenetic relationship}

Phylogenetic analysis indicated that the HA gene of A/Environment/Fujian/85144/2014(H1N8) was clustered with those of H1N8 viruses isolated from local ducks in Fujian Province named A/duck/Fujian/13/2013(H1N8), A/duck/ Fujian/83/2013(H1N8), A/duck/Fujian/89/2013(H1N8) and A/duck/Fujian/84/2013(H1N8). These viruses belong to the avian $\mathrm{H} 1$ group of the Eurasian lineage; they are different from the avian H1N8 North American-lineage viruses and phylogenetically far from swine-origin $\mathrm{H} 1$ and seasonal human $\mathrm{H} 1$ subtype viruses. The N8 gene evolutionary tree indicated that the studied H1N8 virus was most likely derived from the local duck H1N8 viruses and clustered with the duck H6N8 virus isolated from Shantou, Guangdong Province. The N8 gene in the studied virus was clearly different from the N8 genes of avian influenza H1N8 North American-lineage viruses (Fig. 1). According to the phylogenetic analyses of six internal genes, the studied A/Environment/ Fujian/85144/2014(H1N8) virus belongs to the Eurasian lineage and shows phylogenetic diversity. The PB2, PA, NP and NS genes were clustered with those of H7N9 viruses detected in the environment or isolated from ducks in 2017 and 2018 (Additional file 1: Figure S1).

\section{Growth kinetics of the H1N8 virus in DF1, A549 and PK15} cells

The growth kinetics of A/Environment/Fujian/85144/2014 were compared with those of A/Brisbane/59/2007(H1N1), A/duck/Alberta/35/1976(H1N1), and A/swine/Iowa/15/ 1930(H1N1), which are of human origin, avian origin, and swine origin, respectively. The mean peak titres of $\mathrm{A} /$ Environment/Fujian/85144/2014, A/Brisbane/59/2007 (H1N1), A/duck/Alberta/35/1976(H1N1), and A/swine/ Iowa/15/1930(H1N1) in A549 cells were 6, 5.25, 9 and 7.5 $\log _{10} \mathrm{TCID}_{50} / 100 \mu \mathrm{l}$, respectively, while those in the PK15 cell line were $5.5,7,8$ and $9.25 \log _{10} \mathrm{TCID}_{50} / 100 \mu$ l, respectively; however, in the DF1 cell line, the values were $3,2.75$, 4.15 and $4.75 \log _{10} \mathrm{TCID}_{50} / 100 \mu$, respectively. All 4 selected viruses with different origins presented higher titres in A549 and PK15 cells than in DF1 cells $(P<0.05)$. The growth of the A/Environment/Fujian/85144/2014(H1N8) virus in the different cell lines was similar to that of the human-origin virus $\mathrm{A} /$ Brisbane/59/2007(H1N1) and lower than that of the control avian-origin and swine-origin viruses, A/duck/Alberta/35/1976(H1N1) and A/swine/Iowa/ 15/1930(H1N1), respectively (Fig. 2).

\section{Plaque formation assay}

No plaques formed when A/Environment/Fujian/85144/ 2014(H1N8) or the reference seasonal influenza virus A/ Brisbane/59/2007(H1N1) was inoculated into MDCK cells without addition of TPCK-treated trypsin. However, clear plaques of both viruses were present when trypsin was added, and the sizes and shapes of the plaques were similar. This result showed that the studied H1N8 virus is a low-pathogenic avian influenza virus in vitro (Fig. 3).

\section{Receptor binding specificity}

A solid-phase binding assay was used to test six viruses, including 5 reference viruses with different origins. Four different types of sialylglycopolymers $(\alpha 2,3-\mathrm{SL}, \alpha 2,6-\mathrm{SL}, \alpha 2,3-\mathrm{SLN}$ and $\alpha 2,6-\mathrm{SLN})$ were coated on the plates at concentrations of $0,0.625,1.25,2.5,5$ and $10 \mu \mathrm{g} / \mathrm{ml} \mathrm{[18].} \mathrm{As} \mathrm{shown} \mathrm{in} \mathrm{Fig.} \mathrm{4,} \mathrm{A/California/4/}$ 2009(H1N1) bound $\alpha 2,6-S L N$, A/Anhui/1/2005RG(H5N1) bound $\alpha 2,3-\mathrm{SL}$, and A/Brisbane/59/2007(H1N1) bound $\alpha 2,3-\mathrm{SL}, \alpha 2,6-\mathrm{SL}$ and $\alpha 2,6-\mathrm{SLN}$. All three H1 subtype viruses, A/Environment/Fujian/85144/2014(H1N8), A/ duck/Alberta/35/1976(H1N1) and A/swine/Iowa/15/ 1930(H1N1), bound $\alpha 2,3-\mathrm{SL}$ (Fig. 4). The results showed that the reference human H1N1 virus A/California/4/ 2009(H1N1) had a human receptor binding preference, A/ Brisbane/59/2007(H1N1) presented dual receptor binding properties, and $\mathrm{H} 5 \mathrm{~N} 1$ had avian receptor binding characteristics, consistent with previous reports. Our study indicated that all three tested $\mathrm{H} 1$ subtype viruses, including A/Environment/Fujian/85144/2014(H1N8), exhibited avian receptor binding preferences. 


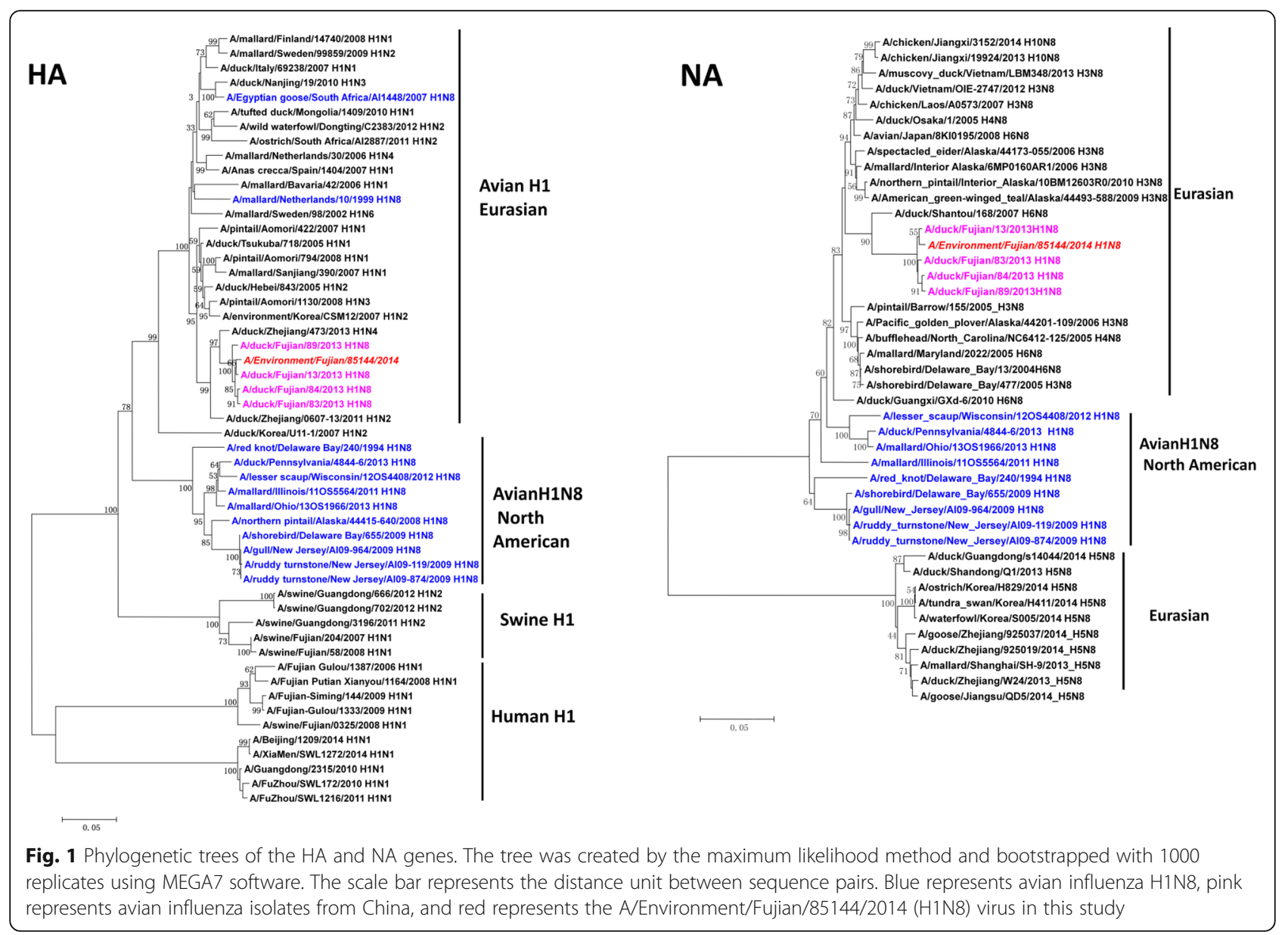

\section{Intravenous pathogenicity index test in chickens}

During the 10-day observation period, only 2 chickens presented mild signs and cough as early as 2 days after infection. The other chickens, including those in the test and control groups, appeared normal until the end of observation. The IVPI in the chickens was 0.02 , which indicated that A/Environment/Fujian/85144/2014(H1N8) is a low-pathogenic avian influenza virus.

\section{Discussion}

H1 subtype influenza viruses are known for their wide range of hosts (from birds to mammalian species such as pigs and humans) and rapid evolution as a result of antigenic drift and antigenic shift, which can cause seasonal influenza epidemics and even influenza pandemics $[1,19,20]$. The phylogenetic analysis showed that $\mathrm{H} 1$ subtype influenza viruses have distinct lineages that can be separated based on avian, human and swine origins. Cross-species transmission events of $\mathrm{H} 1$ subtype influenza virus have happened occasionally [21-23]. Our study showed that the H1N8 avian influenza virus A/Environment/Fujian/85144/2014(H1N8) is derived from avian-origin viruses and is evolutionarily distant from mammalian viruses. Although avian-origin influenza viruses are distant from mammalian ones, they still make genomic contributions to the evolution of mammalian viruses [24]. We should be vigilant about the potential emergence of pandemics due to avian influenza H1 subtype viruses.

Research on avian influenza virus ecology in LPMs in China has demonstrated that $\mathrm{H} 5, \mathrm{H} 9$, and $\mathrm{H} 7$ are not the only subtypes of avian influenza viruses; subtypes such as $\mathrm{H} 3, \mathrm{H} 4, \mathrm{H} 6, \mathrm{H} 1$, and $\mathrm{H} 2$ are also present $[6,25]$. A few studies have indicated that $\mathrm{H} 1 \mathrm{~N} 2, \mathrm{H} 1 \mathrm{~N} 1$, and H1N3 are relatively easy to detect, although both H1N4 and H1N9 had been isolated as well [26, 27]. To our knowledge, the H1N8 subtype has rarely been detected $[28,29]$. Our study may be the first systematic study of the biological and genetic characteristics of the H1N8 avian influenza virus, which was isolated from live poultry market-related environments in China.

Receptor binding preference plays an important role in influenza replication and transmission. The ability of avian influenza virus to bind to the human receptor is the basis for efficient human-to-human transmission. The relationship between human receptor binding specificity and HA 


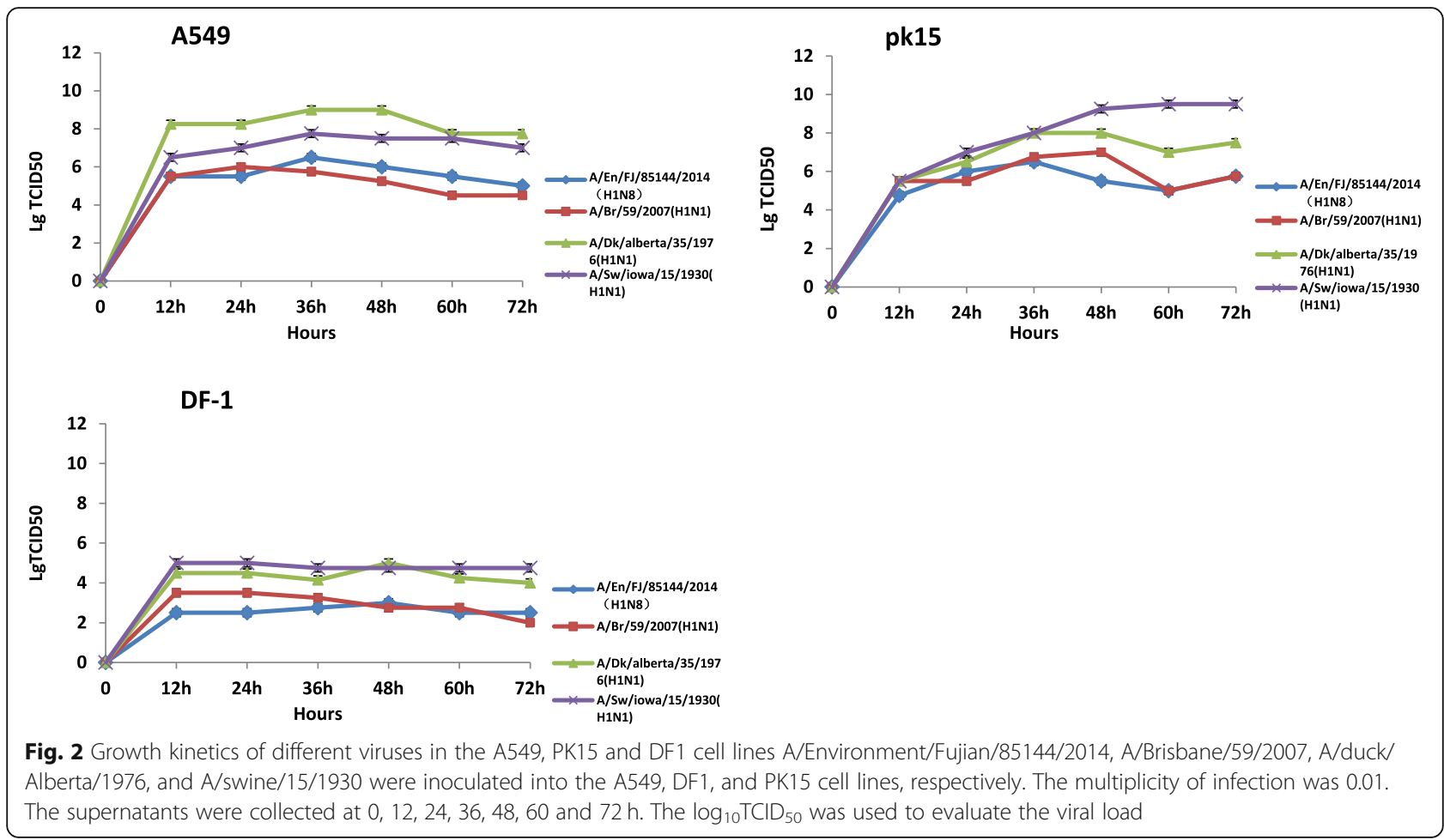

gene molecular markers has been extensively revealed in H5, H7 and H9 subtype viruses [22, 30]. Based on the solid-phase binding assay results, the studied H1N8 virus still has an avian receptor binding preference.

Plaque formation assays are some of the most quantitative and useful biological methods for virus research and can be used for quantification of infectivity and identification of individual virus particles with specific biological features. We intended to determine the pathogenicity of the H1N8 avian influenza virus in vitro using this assay. If a virus is highly pathogenic, a plaque can be formed without trypsin present. This property is based on the presence of multiple basic amino acids at the cleavage site of the HA protein [31]. We found that the H1N8 virus needed trypsin to form plaques, which indicated its low-pathogenic avian influenza characteristics. This phenotype is supported by the sequence of the HA cleavage site, PSVQSR/GLF, which has only one basic amino acid.

Virus growth curves in different cell lines can be used to describe virus replication and proliferation ability. In our study, the H1N8 virus grew better in A549 and PK15 cells than in DF1 cells, which indicated the possibility of a growth preference for mammalian cells. A sharp increase in virus replication was detected $12 \mathrm{~h}$ post infection in the A549 and DF1 cells. However, the virus growth in PK15 cells increased to a peak at $36 \mathrm{~h}$ post infection. A/Environment/Fujian/85144/2014 displayed avian receptor binding characteristics, indicating that the virus retains avian influenza binding capacity. Despite its great similarity with other avian influenza viruses and its low pathogenicity to poultry, this H1N8 subtype avian influenza virus presented efficient replication in mammalian cells, indicating its potential risk for poultry and even mammals. Further exploration will be beneficial to enhance understanding of the mechanism of H1N8 infection in birds and mammals.

The PB2, PA, and NS genes of the H1N8 virus studied showed the highest similarity with a highly pathogenic avian influenza (HPAI) H7N9 virus, A/Environment/Fujian/S10058/2017(H7N9), which was reported in 2018 [32]. Although the H1N8 NP gene was most similar to that of the H1N2 virus, it shared high similarity and clustered with those of the H7N9 viruses detected in 2017 and 2018. These HPAI H7N9 viruses were detected in poultry in China [32] and did not present the same gene constellations as HPAI H7N9 viruses possessing internal genes from $\mathrm{H} 9 \mathrm{~N} 2$ viruses that crossed species barriers and caused sporadic human infections [11]. Our study showed that the same genetic pool (the PB2, PA, NP, and NS genes) that circulated in 2014 was still present in 2017, indicating that A/Environment/Fujian/ 85144/2014(H1N8) acted as a gene carrier and was involved in the evolution of H7N9 viruses in poultry. Active surveillance of avian influenza in LPMs is a major pillar supporting avian influenza control and response. 


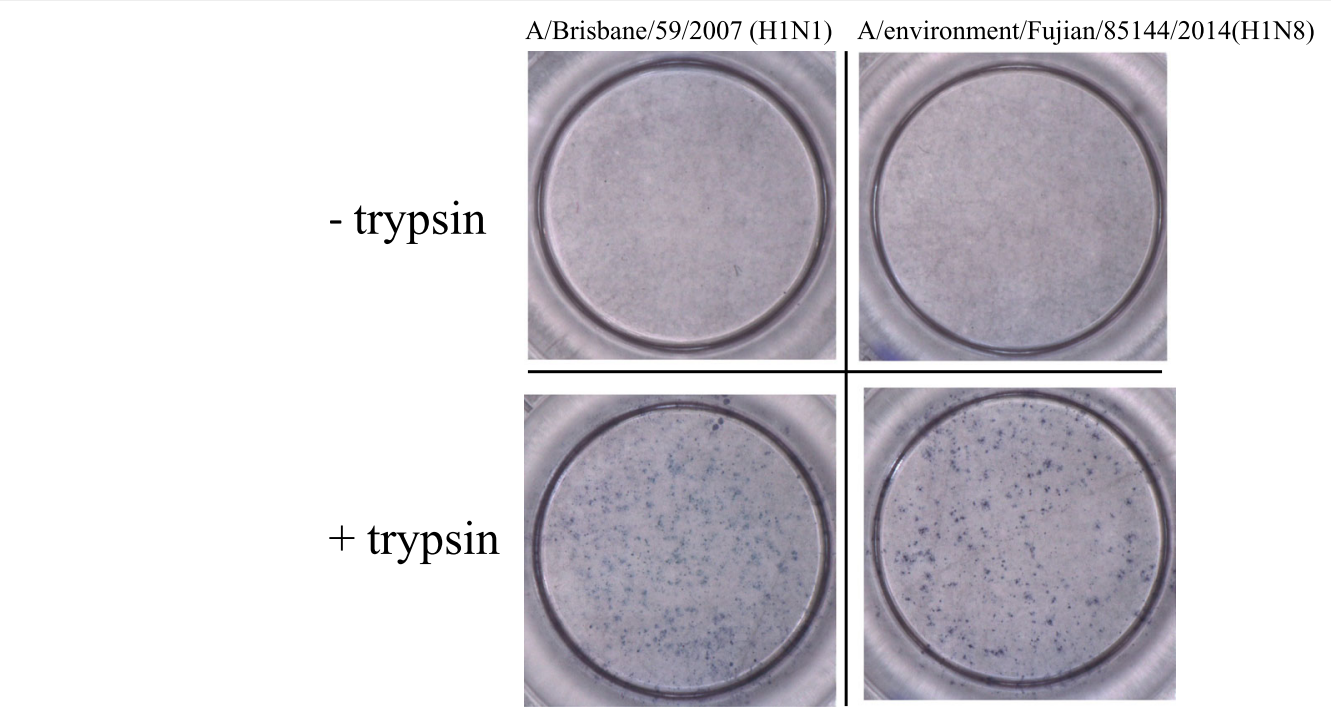

Fig. 3 Plaque formation in MDCK cells with or without TPCK-treated trypsin. A/Environment/Fujian/85144/2014(H1N8) and A/Brisbane/59/ 2007(H1N1) were inoculated into MDCK cells with or without TPCK-treated trypsin $(2 \mu \mathrm{g} / \mathrm{ml})$ at $37^{\circ} \mathrm{C}$ overnight. Both viruses produced clear plaques with trypsin present, while no plaques were produced without trypsin

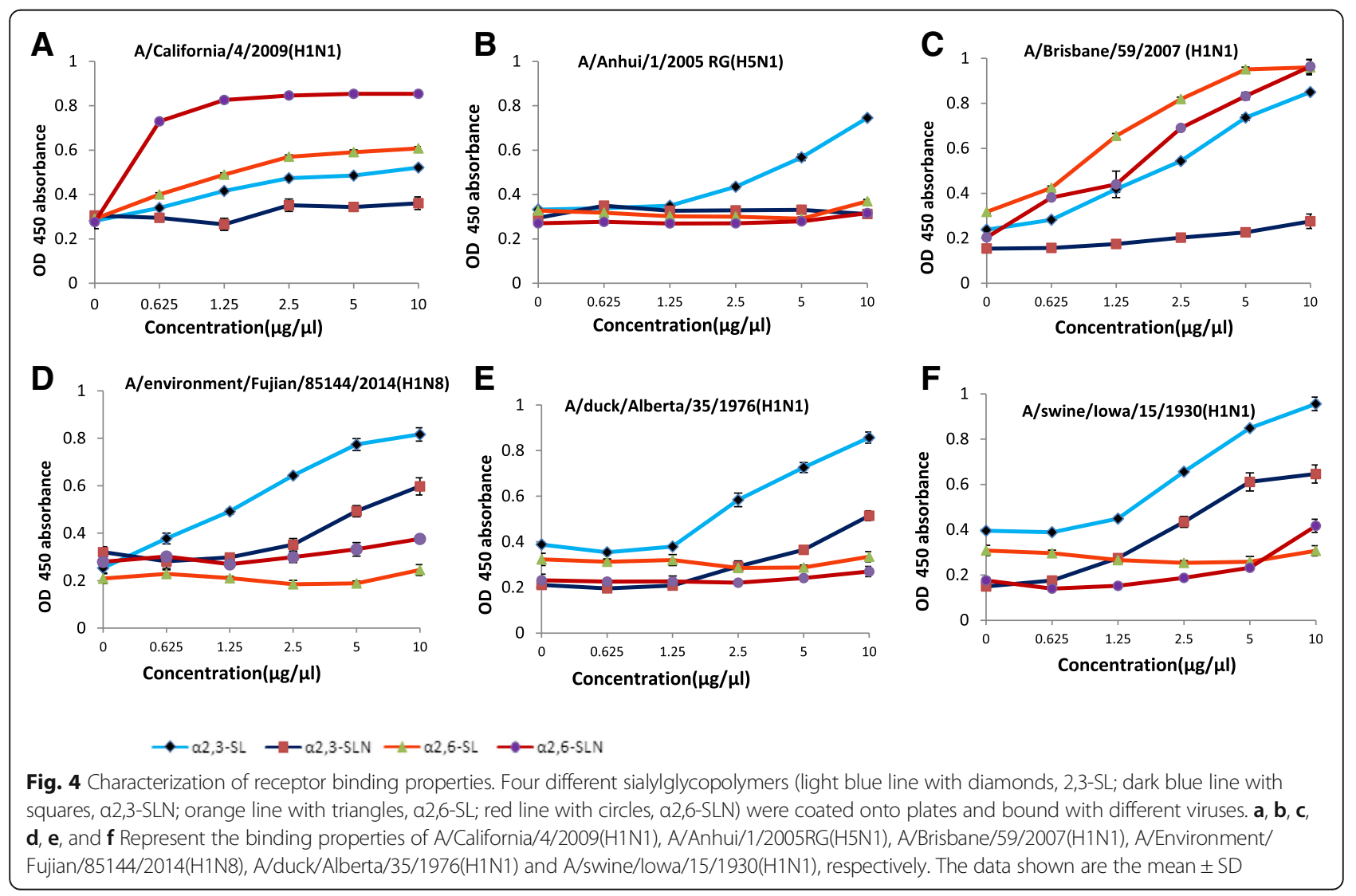




\section{Conclusions}

The H1N8 influenza virus in this study contained a gene constellation of avian origin and might have been involved in the evolution of H7N9 viruses in poultry. In addition, an avian receptor binding preference was present, and low pathogenicity to poultry was confirmed both in vitro and in vivo. This H1N8 virus can also grow well in mammalian cells. Although this subtype of virus is not frequently detected, it still contributes to the diversity of avian influenza ecology and provides some insights for virus surveillance. The results of this study also emphasize the forecasting function of LPMs regarding the trends in avian influenza activity in China.

\section{Additional file}

Additional file 1: Figure S1. Phylogenetic analysis of six internal genes of A/Environment/Fujian/85144/2014(H1N8). Phylogenetic analysis of six internal genes, including PB2, PB1, PA, NP, M, and NS. All sequences were downloaded from GenBank. The maximum likelihood method was used to construct the phylogenetic trees. The virus strains are marked with different colours. Red represents the A/Environment/Fujian/85144/2014(H1N8) strain in this study, blue represents other H1N8 subtype viruses, pink represents all available previous H1N8 subtype viruses sequence from China, black represents viruses of other subtypes, and the black star indicates the HPAl H7N9 viruses isolated in 2017 and 2018. (PDF $1538 \mathrm{~kb}$ )

\section{Abbreviations}

A549: Human type II alveolar epithelial cell line; DF1: DF1 Chicken embryo fibroblasts cell line; HA: Haemagglutinin; IVPI: Intravenous pathogenicity index; LPM: Live poultry market; NA: Neuraminidase; PK15: Porcine Kidney cell line; SPF: Specific pathogen free; $\mathrm{TCID}_{50}: 50 \%$ Tissue culture infective dose; TPCK: 6- (1-tosylamido-2-phenyl) ethyl chloromethyl ketone; TRBC: Turkey red blood cell

\section{Acknowledgements}

We appreciated Chinese National Influenza Surveillance Network for specimen collection and shipment.

\section{Funding}

This study was supported by the National Key Research and Development Program (2016YFD0500208 to Dayan Wang) and China-US collaborative program on emerging and re-emerging infectious disease.

\section{Availability of data and materials}

All data generated or analyzed during this study are included in this published article. The full genome sequences of the virus in this study were submitted to GISAID.

\section{Authors' contributions}

YZ performed virus isolation, drafted the manuscript and analyzed data; JD drafted the manuscript, performed receptor binding assay and analyzed data; HB conducted RNA extraction; LD did Animal experiments; SZ did receptor binding assay; $\mathrm{XL}$ performed gene sequencing; $Y S$ designed the surveillance; DW designed the experiment, revised the manuscript and approved the version to be published. All authors have read and approved the manuscript.

\section{Ethics approval}

The experiments were performed at the Biosafety Level-2 laboratory at the Animal Center of Chinese Center for Disease Control and Prevention (China CDC). The animal experiments were approved (No.20180823033) by the Animal Ethics Committee of National Institute for Viral Disease Control and Prevention, China CDC.

\section{Consent for publication}

Not applicable.

\section{Competing interests}

The authors declare that they have no competing interests.

\section{Publisher's Note}

Springer Nature remains neutral with regard to jurisdictional claims in published maps and institutional affiliations.

\section{Author details}

${ }^{1}$ Chinese National Influenza Centre, National Institute for Viral Disease Control and Prevention, Chinese Center for Disease Control and Prevention; WHO Collaborating Center for Reference and Research on Influenza; Key Laboratory for Medical Virology, National Health and Family Planning Commission, Beijing, China. ${ }^{2}$ Present Address: Public Health School (Shenzhen), Sun Yat-sen University, Guangzhou, China.

Received: 22 March 2019 Accepted: 10 May 2019

Published online: 22 May 2019

\section{References}

1. Webster RG, Bean WJ, Gorman OT, Chambers TM, Kawaoka Y. Evolution and ecology of influenza a viruses. Microbiol Rev. 1992;56(1):152-79.

2. Freidl GS, Meijer A, de Bruin E, de Nardi M, Munoz O, Capua I, Breed AC Harris K, Hill A, Kosmider R, et al: Influenza at the animal-human interface: a review of the literature for virological evidence of human infection with swine or avian influenza viruses other than A(H5N1). Eur Surveill. 2014; 19(18). https://doi.org/10.2807/1560-7917.ES.2014.19.18.20793.

3. Van Kerkhove MD. Brief literature review for the WHO global influenza research agenda--highly pathogenic avian influenza H5N1 risk in humans. Influenza Other Respir Viruses. 2013;7(Suppl 2):26-33.

4. Yu H, Wu JT, Cowling BJ, Liao Q, Fang VJ, Zhou S, Wu P, Zhou H, Lau EH, Guo D, et al. Effect of closure of live poultry markets on poultry-to-person transmission of avian influenza a H7N9 virus: an ecological study. Lancet. 2014:383(9916):541-8.

5. Fournie G, Guitian J, Desvaux S, Cuong VC, Dung do H, Pfeiffer DU, Mangtani P, Ghani AC. Interventions for avian influenza a (H5N1) risk management in live bird market networks. Proc Natl Acad Sci U S A. 2013; 110(22):9177-82.

6. Liu M, He S, Walker D, Zhou N, Perez DR, Mo B, Li F, Huang X, Webster RG, Webby RJ. The influenza virus gene pool in a poultry market in south Central China. Virology. 2003;305(2):267-75.

7. He Y, Liu P, Tang S, Chen Y, Pei E, Zhao B, Ren H, Li J, Zhu Y, Zhao H, et al. Live poultry market closure and control of avian influenza $A(\mathrm{H} 7 \mathrm{~N} 9)$, Shanghai, China. Emerg Infect Dis. 2014;20(9):1565-6.

8. Huo X, Chen L, Oi X, Huang H, Dai Q, Yu H, Xia Y, Liu W, Xu K, Ma W, et al. Significantly elevated number of human infections with H7N9 virus in Jiangsu in eastern China, October 2016 to January 2017. Euro Surveill. 2017; 22(13). https://doi.org/10.2807/1560-7917.ES.2017.22.13.30496.

9. Yuan J, Lau EH, Li K, Leung YH, Yang Z, Xie C, Liu Y, Liu Y, Ma X, Liu J, et al. Effect of live poultry market closure on avian influenza $A(H 7 N 9)$ virus activity in Guangzhou, China, 2014. Emerg Infect Dis. 2015;21(10):1784-93.

10. Childs RA, Palma AS, Wharton S, Matrosovich T, Liu Y, Chai W, CampaneroRhodes MA, Zhang Y, Eickmann M, Kiso M, et al. Receptor-binding specificity of pandemic influenza a (H1N1) 2009 virus determined by carbohydrate microarray. Nat Biotechnol. 2009;27(9):797-9.

11. Zhu W, Zhou J, Li Z, Yang L, Li X, Huang W, Zou S, Chen W, Wei H, Tang J, et al. Biological characterisation of the emerged highly pathogenic avian influenza (HPAl) A(H7N9) viruses in humans, in mainland China, 2016 to 2017. Euro Surveill. 2017;22(19). https://doi.org/10.2807/1560-7917.ES.2017. 22.19.30533.

12. Dong J, Bo H, Zhang Y, Dong L, Zou S, Huang W, Liu J, Wang D, Shu Y. Characteristics of influenza H13N8 subtype virus firstly isolated from Qinghai Lake region, China. Virol J. 2017;14(1):180.

13. World Organization for Animal Health. Manual of diagnostic tests and vaccines for terrestrial animals. 2018(OlE):826.

14. Shinya K, Hamm S, Hatta M, Ito H, Ito T, Kawaoka Y. PB2 amino acid at position 627 affects replicative efficiency, but not cell tropism, of Hong Kong H5N1 influenza a viruses in mice. Virology. 2004;320(2):258-66. 
15. Fan S, Deng G, Song J, Tian G, Suo Y, Jiang Y, Guan Y, Bu Z, Kawaoka Y, Chen $\mathrm{H}$. Two amino acid residues in the matrix protein $\mathrm{M} 1$ contribute to the virulence difference of $\mathrm{H} 5 \mathrm{~N} 1$ avian influenza viruses in mice. Virology. 2009;384(1):28-32.

16. Choi WS, Jeong JH, Kwon JJ, Ahn SJ, Lloren KKS, Kwon HI, Chae HB, Hwang J, Kim MH, Kim CJ, et al. Screening for Neuraminidase Inhibitor Resistance Markers among Avian Influenza Viruses of the N4, N5, N6, and N8 Neuraminidase Subtypes. J Virol. 2018;92(1). https://doi.org/10.1128/JVI. 01580-17.

17. Jiao P, Tian G, Li Y, Deng G, Jiang Y, Liu C, Liu W, Bu Z, Kawaoka Y, Chen H. A single-amino-acid substitution in the NS1 protein changes the pathogenicity of H5N1 avian influenza viruses in mice. J Virol. 2008;82(3):1146-54.

18. Yang ZY, Wei CJ, Kong WP, Wu L, Xu L, Smith DF, Nabel GJ. Immunization by avian $\mathrm{H} 5$ influenza hemagglutinin mutants with altered receptor binding specificity. Science. 2007:317(5839):825-8.

19. Worobey M, Han GZ, Rambaut A. Genesis and pathogenesis of the 1918 pandemic H1N1 influenza a virus. Proc Natl Acad Sci U S A. 2014;111(22): 8107-12.

20. Belser JA, Wadford DA, Pappas C, Gustin KM, Maines TR, Pearce MB, Zeng H, Swayne DE, Pantin-Jackwood M, Katz JM, et al. Pathogenesis of pandemic influenza a ( $\mathrm{H} 1 \mathrm{~N} 1)$ and triple-reassortant swine influenza a $(\mathrm{H} 1)$ viruses in mice. J Virol. 2010;84(9):4194-203.

21. Brockwell-Staats C, Webster RG, Webby RJ. Diversity of influenza viruses in swine and the emergence of a novel human pandemic influenza a ( $\mathrm{H} 1 \mathrm{~N} 1)$. Influenza Other Respir Viruses. 2009;3(5):207-13.

22. Bourret V, Lyall J, Frost SDW, Teillaud A, Smith CA, Leclaire S, Fu J, Gandon S, Guerin JL, Tiley LS. Adaptation of avian influenza virus to a swine host. Virus Evol. 2017;3(1):vex007.

23. Pippig J, Ritzmann M, Buttner M, Neubauer-Juric A. Influenza a viruses detected in swine in southern Germany after the H1N1 pandemic in 2009. Zoonoses Public Health. 2016;63(7):555-68.

24. Kocer ZA, Carter R, Wu G, Zhang J, Webster RG. The genomic contributions of avian $\mathrm{H} 1 \mathrm{~N} 1$ influenza a viruses to the evolution of mammalian strains. PLoS One. 2015;10(7):e0133795.

25. Zhao G, Pan J, Gu X, Zhao K, Chen H, Chen S, Wang X, Peng D, Liu X. Prevalence of low pathogenic avian influenza virus in one live bird market in eastern China from 2002-2011. Avian Dis. 2013:57(1):155-8.

26. Wu H, Lu R, Peng X, Liu F, Cheng L, Wu N. Characterization of reassortant H1-subtype avian influenza viruses isolated from poultry in Zhejiang Province in China from 2013 to 2015. Arch Virol. 2017;162(11):3493-500.

27. Ge Y, Yao QC, Wang XF, Fan ZQ, Deng GH, Chai HL, Chen HL, Hua YP. Epidemic of wild-origin H1NX avian influenza viruses in Anhui, China. Infect Dis Poverty. 2017;6(1):98.

28. Abolnik C, Gerdes GH, Sinclair M, Ganzevoort BW, Kitching JP, Burger CE, Romito M, Dreyer M, Swanepoel S, Cumming GS, et al. Phylogenetic analysis of influenza a viruses (H6N8, H1N8, H4N2, H9N2, H10N7) isolated from wild birds, ducks, and ostriches in South Africa from 2007 to 2009. Avian Dis. 2010;54(1 Suppl):313-22

29. Cumming GS, Caron A, Abolnik C, Cattoli G, Bruinzeel LW, Burger CE, Cecchettin K, Chiweshe N, Mochotlhoane B, Mutumi GL, et al. The ecology of influenza a viruses in wild birds in southern Africa. EcoHealth. 2011;8(1):4-13.

30. Chen LM, Blixt O, Stevens J, Lipatov AS, Davis CT, Collins BE, Cox NJ, Paulson $\mathrm{JC}$, Donis RO. In vitro evolution of H5N1 avian influenza virus toward human-type receptor specificity. Virology. 2012;422(1):105-13.

31. Matrosovich MN, Krauss S, Webster RG. H9N2 influenza a viruses from poultry in Asia have human virus-like receptor specificity. Virology. 2001; 281(2):156-62.

32. Shi J, Deng G, Ma S, Zeng X, Yin X, Li M, Zhang B, Cui P, Chen Y, Yang H, et al. Rapid evolution of H7N9 highly pathogenic viruses that emerged in china in 2017. Cell Host Microbe. 2018:24(4):558-568 e557.

Ready to submit your research? Choose BMC and benefit from:

- fast, convenient online submission

- thorough peer review by experienced researchers in your field

- rapid publication on acceptance

- support for research data, including large and complex data types

- gold Open Access which fosters wider collaboration and increased citations

- maximum visibility for your research: over $100 \mathrm{M}$ website views per year

At $\mathrm{BMC}$, research is always in progress.

Learn more biomedcentral.com/submissions 